\title{
Molecular Mapping of the Stb4 Gene for Resistance to Septoria tritici Blotch in Wheat
}

\author{
Tika B. Adhikari, Jessica R. Cavaletto, Jorge Dubcovsky, Jorge Omar Gieco, \\ Ana Rosa Schlatter, and Stephen B. Goodwin
}

First, second, and sixth authors: Crop Production and Pest Control Research, U.S. Department of Agriculture-Agricultural Research Service, Department of Botany and Plant Pathology, 915 W. State Street, Purdue University, West Lafayette, IN 47907; third and fifth authors: Department of Agronomy and Range Science, University of California, Davis 95616; and fourth author: USP/ESALQ, Departamento de Genética, C.P. 83, 13400-970, Piracicaba, SP, Brazil.

Current address of T. B. Adhikari: Department of Plant Pathology, 306 Walster Hall, North Dakota State University, Fargo 58105.

Current address of J. O. Gieco: Biotecnología en Cultivos, INTA-Estación Experimental Agropecuaria Manfredi, Ruta Nac. No 9 Km. 636,

C.P. 5988-Manfredi (Pcia. de Córdoba), Argentina.

Accepted for publication 19 July 2004

\section{ABSTRACT}

Adhikari, T. B., Cavaletto, J. R., Dubcovsky, J., Gieco, J. O., Schlatter, A. R., and Goodwin, S. B. 2004. Molecular mapping of the Stb4 gene for resistance to Septoria tritici blotch in wheat. Phytopathology 94:1198-1206.

Breeding wheat for resistance is the most effective means to control Septoria tritici blotch (STB), caused by the ascomycete Mycosphaerella graminicola (anamorph Septoria tritici). At least eight genes that confer resistance to STB in wheat have been identified. Among them, the Stb4 locus from the wheat $\mathrm{cv}$. Tadinia showed resistance to $M$. graminicola at both seedling and adult-plant stages. However, no attempt has been made to map the Stb4 locus in the wheat genome. A mapping population of 77 $\mathrm{F}_{10}$ recombinant-inbred lines (RILs) derived from a three-way cross between the resistant cv. Tadinia and the susceptible parent (Yecora Rojo $\times$ UC554) was evaluated for disease resistance and molecular mapping. The RILs were tested with Argentina isolate I 89 of M. graminicola for one greenhouse season in Brazil during 1999, with an isolate from Brazil (IPBr1) for one field season in Piracicaba (Brazil) during 2000, and with Indiana tester isolate IN95-Lafayette-1196-WW-1-4 in the greenhouse during 2000 and 2001. The ratio of resistant:susceptible RILs was 1:1 in all three tests, confirming the single-gene model for control of resistance to STB in Tadinia. However, the patterns of resistance and susceptibility were different between the Indiana isolate and those from South America. For example, the ratio of RILs resistant to both the Indiana and Argentina isolates, resistant to one but susceptible to the other, and susceptible to both isolates was approximately $1: 1: 1: 1$, indicating that Tadinia may contain at least two genes for resistance to STB. A similar pattern was observed between the Indiana and Brazil isolates. The gene identified with the Indiana tester isolate was assumed to be the same as Stb4, whereas that revealed by the South American isolates may be new. Bulked-segregant analysis was used to identify amplified fragment length polymorphism (AFLP) and microsatellite markers linked to the presumed Stb4 gene. The AFLP marker EcoRI-ACTG/MseI-CAAA5 and microsatellite Xgwm111 were closely linked to the $S t b 4$ locus in coupling at distances of 2.1 and 0.7 centimorgans $(\mathrm{cM})$, respectively. A flanking marker, AFLP EAGG/M-CAT10, was $4 \mathrm{cM}$ from Stb4. The Stb4 gene was in a potential supercluster of resistance genes near the centromere on the short arm of wheat chromosome 7D that also contained Stb5 plus five previously identified genes for resistance to Russian wheat aphid. The microsatellite marker Xgwm111 identified in this study may be useful for facilitating the transfer of $S t b 4$ into improved cultivars of wheat.

Additional keywords: marker-assisted selection, Triticum aestivum.
Septoria tritici blotch (STB), caused by the ascomycete fungus Mycosphaerella graminicola (asexual stage: Septoria tritici), is one of the most destructive foliar diseases of wheat (Triticum aestivum L. em. Thell) worldwide $(15,16)$. Severity levels of this disease have increased in many parts of the world due to replacement of traditional tall cultivars by high-yielding, semi-dwarf wheat cultivars (15). In the United States, STB was first reported in 1929 from California (28). Subsequently, it was found to be widespread in the Pacific Northwest (10), northern Great Plains (51), and eastern soft-wheat regions (43). Frequent rainfall and moderate temperatures are the major factors contributing to the

Corresponding author: S. B. Goodwin; E-mail address: sgoodwin@purdue.edu

Names are necessary to report factually on available data. However, the United States Department of Agriculture neither guarantees nor warrants the standard of the product, and the use of the name implies no approval of the product to the exclusion of others that also may be suitable.

\section{Publication no. P-2004-0913-04R}

This article is in the public domain and not copyrightable. It may be freely reprinted with customary crediting of the source. The American Phytopathological Society, 2004 development of STB epidemics $(15,19,42)$. Severe epidemics reduce both quality and yield, and losses of up to $50 \%$ have been reported $(16,44)$. Deployment of resistant cultivars is the only economical method for controlling this disease in most parts of the world (15).

An understanding of the inheritance and map locations of resistance genes will improve the efficiency of breeding for increased resistance to STB. Genetic resistance to STB can be expressed as a reduction in lesion size, as reduced percentage of leaf area covered by pycnidia, or both $(15,23,47)$. The inheritance of resistance to STB has been reported to be conditioned by additive, dominant, partially dominant, or recessive gene action $(41,49)$. Until now, eight major genes for resistance to STB have been identified in wheat: Stb1 (38), Stb2 and Stb3 (49), Stb4 (47), Stb5 (4), Stb6 (9), Stb7 (30), and Stb8 (1). Molecular markers such as restriction fragment length polymorphisms (RFLPs), simplesequence repeats (SSRs or microsatellite markers), and amplified fragment length polymorphisms (AFLPs) (48) recently have been used to tag seven of the STB resistance genes in wheat.

The spring wheat cv. Tadinia (20) possesses the single dominant gene Stb4 for resistance (47). This gene has been useful for controlling M. graminicola in California since 1975 (47), yet its 
map location and relationship to other mapped genes for resistance to STB are not known. The utility of this gene in breeding programs would be increased greatly by the availability of linked molecular markers. Development of such markers would expedite the selection of favorable gene combinations by marker-assisted selection to pyramid this gene with others in wheat breeding programs. The objectives of this study were to analyze the inheritance of Stb4 resistance to M. graminicola, identify molecular markers closely linked to the gene, and map its chromosomal location in the wheat genome.

\section{MATERIALS AND METHODS}

Plant materials. Tadinia is an STB-resistant cultivar derived from the cross Tadorna $\times$ Inia 66 . It has the $S t b 4$ gene for resistance that is expressed in both seedling and adult-plant stages under both field and greenhouse conditions (47). The susceptible parent used in this study was an $\mathrm{F}_{1}$ derived from the cross between Yecora Rojo and UC554 (hereafter referred to as the susceptible parent). Both Yecora Rojo and UC554 are highly susceptible to STB. A three-way cross was made between the resistant Tadinia and the susceptible parent, and $77 \mathrm{~F}_{10}$ recombinantinbred lines (RILs) were derived after 10 generations of self pollination without selection at the University of California, Davis.

STB evaluation in the greenhouse. The $\mathrm{F}_{10}$ RILs were evaluated for resistance to $M$. graminicola in a greenhouse of the Department of Botany and Plant Pathology, Purdue University, West Lafayette, IN during 2000 and 2001. Inoculum preparation, inoculation with field isolate IN95-Lafayette-1196-WW-1-4 of $M$. graminicola, experimental design, and disease assessment were as described previously (1). Plants were inoculated once the flag leaves were expanded fully, approximately 7 weeks after transplanting, in a randomized, complete-block design. The $77 \mathrm{~F}_{10}$ RILs, Tadinia, and Yecora Rojo were included in all tests. The third parent, UC554, was included in most, but not all, of the tests. Each pot contained a single plant of a parent or RIL and each inoculated plant was treated as an experimental unit. Each treatment was replicated three to six times during both years.

Symptoms of STB were assessed from 21 to 28 days after inoculation. Inoculated plants were rated by two disease-assessment methods $(17,23,41)$ : (i) disease severity (DS) was based on the visually estimated percentage of leaf area of necrotic lesions containing pycnidia, and (ii) average pycnidial density was rated within necrotic lesions with a score ranging from 0 to 5 , where $0=$ no pycnidia and $5=$ maximum pycnidial production (1). Means of DS and pycnidial density were calculated over all plants tested for each year. A disease index was calculated for each parent and RIL by multiplying DS by pycnidial density, and a mean disease index was calculated over both years. A few lines with poor seed germination or that gave inconclusive results were retested with parental controls during 2002. The experimental entries were classified as $\mathrm{R}=$ resistant or $\mathrm{S}=$ susceptible based on the mean disease index, and these classifications were used for genetic and linkage analyses. The disease index was used because it combined severity and pycnidial density into a single number and it provided a clear separation between resistant and susceptible lines in preliminary testing, and $\chi^{2}$ statistics were used to determine goodness of fit with expected segregation ratios.

A second greenhouse test was done in Piracicaba, São Paulo, Brazil, during 1999. Seeds of Tadinia, Yecora Rojo, the $77 F_{10}$ RILs, and the additional resistant control UC1041 were planted in pots (eight pots per parent and RIL/replication) and arranged in a randomized block design with three replications. Plants were inoculated as described above with isolate I 89 of M. graminicola, which was collected originally from cv. Klein Cacique grown in Barrow, Buenos Aires, Argentina. Two inoculations were made, the first at tillering and the second at the flag-leaf stage. The percent leaf area covered by lesions was estimated by visual inspec- tion when symptoms had developed after each inoculation. The two scores were averaged to derive the overall mean for each parent and RIL.

STB evaluation in the field. Monopycnidial isolate IPBr1 was obtained from wheat leaves of the susceptible cv. Cooperación Calquin that were infected naturally with $M$. graminicola in Piracicaba, Brazil. Fungal isolation was made by placing leaf segments bearing pycnidia in petri plates lined with moistened filter paper overnight, and transferring cirrhi individually with a sterile needle to plates of yeast-malt agar amended with streptomycin at $50 \mathrm{mg} /$ liter. After isolation, the fungus was maintained on petri plates containing AMYS medium (14 $\mathrm{g}$ of agar, $4 \mathrm{~g}$ of malt extract, $4 \mathrm{~g}$ of yeast extract, and $4 \mathrm{~g}$ of sucrose in 1 liter of distilled water) in a growth chamber at $16 \pm 1^{\circ} \mathrm{C}$ with a 12 -h photoperiod, and transferred every 60 days. Inoculum was prepared by inoculating $250 \mathrm{ml}$ of liquid yeast-glucose medium in 500-ml Erlenmeyer flasks with fresh pieces of $M$. graminicola colonies from agar plates. Erlenmeyer flasks were incubated for 7 days in a temperature-controlled shaker at $16^{\circ} \mathrm{C}$. After sporulation, the liquid media were filtered and adjusted to a density of $10^{7}$ spores $/ \mathrm{ml}$ with distilled water.

Field data were from a previously published experiment (18) conducted in Piracicaba, using a randomized block design with four replications. The $77 \mathrm{~F}_{10}$ lines plus the three parental cultivars were planted in $1-\mathrm{m}$ rows of eight plants, each spaced $0.17 \mathrm{~m}$ apart. The susceptible control "Cooperación Calquin" was used as a spreader row around each block. The experiment was planted during June 2000 and inoculated 60 days after planting at the flag-leaf stage as described previously (18). At 30 days after inoculation, disease was evaluated by visual estimation of damaged leaf area (DLA). DLA was assessed as the percentage of the flag leaf area covered with pycnidia using a rating scale where $0=$ absence of pycnidia, $1=12,2=25,3=50,4=75$, and $5=$ $87 \%$ of the leaf area covered with pycnidia (14).

DNA extraction. Young wheat leaves were harvested from the three parents and 70 of the $F_{10}$ RILs 1 week after seed germination. The harvested leaves were frozen at $-80^{\circ} \mathrm{C}$, lyophilized for $72 \mathrm{~h}$, and stored at $-80^{\circ} \mathrm{C}$. Genomic DNA was isolated from lyophilized tissue with the DNeasy Plant Mini kit according to the manufacturer's directions (Qiagen, Valencia, CA) or by the cetyltrimethylammonium bromide (CTAB) method (34). Each DNA sample was quantified by fluorometer (Hoefer Scientific Instruments, San Francisco) and adjusted to $25 \mathrm{ng} / \mu \mathrm{l}$ or $6 \mathrm{ng} / \mu \mathrm{l}$ for AFLP and microsatellite analysis, respectively. Seed germination for seven lines was poor and these were excluded from the molecular analyses.

Bulked-segregant analysis. Bulked-segment analysis (BSA) (33) was performed based on the Indiana greenhouse phenotypic data. For AFLP and microsatellite analysis, two DNA bulks were assembled by using equal amounts of DNA from resistant and susceptible $\mathrm{F}_{10}$ RILs. The number of individuals in each bulk was 10 for AFLP analysis and 6 for the microsatellite markers. Band patterns of the bulks were compared with those from the three parents (Tadinia, Yecora Rojo, and UC554) to identify potential markers linked to the resistance locus. A total of 80 AFLP primer combinations and 240 microsatellite primer pairs from different wheat genomes was screened using BSA.

AFLP analysis. AFLP analysis was conducted using AFLP Analysis System I, AFLP Start Primer Kit (Invitrogen Life Technologies, Carlsbad, CA), as described by Vos et al. (48) with the modifications of Adhikari et al. (1). Briefly, $10 \mu \mathrm{l}$ of genomic DNA $(25 \mathrm{ng} / \mu \mathrm{l})$ of each parent and all $70 \mathrm{~F}_{10}$ RILs were digested simultaneously in a reaction volume of $25 \mu \mathrm{l}$ with 2.5 units each of EcoRI and $M s e I$ restriction enzymes, and ligated to EcoRI and $M s e$ I adapters. The digested DNA, together with 2 pmol of EcoRI adapters and $20 \mathrm{pmol}$ of $\mathrm{MseI}$ adapters, were ligated with 1 unit of T4 ligase. The ligation mix was incubated at $20^{\circ} \mathrm{C}$ for $2 \mathrm{~h}$, then the enzyme was inactivated at $70^{\circ} \mathrm{C}$ for $15 \mathrm{~min}$. The ligated 
product was diluted 10 fold in Tris-EDTA (TE) $(10 \mathrm{mM}$ Tris- $\mathrm{HCl}$ pH 8.0, 0.1 mM EDTA). Pre-amplification, primer labeling, selective amplification, electrophoresis, and photography were as described previously (1). The following AFLP primer extensions were used for the selective amplification: AAC, AAG, ACA, ACC, ACG, AGC, AGG, ACT, ACTT, ACTA, ACTG, and ACTC for the EcoRI primer; and CAC, CAG, CAT, CTA, CTC, CTG, CTT, CAA, CAAA, CAAT, CAAG, and CAAC for MseI. The AFLP bands were scored by visual inspection, and AFLP loci were named based on the combination of selective nucleotides in each primer (EcoRI and MseI) and the relative size of the band. For example, AGG/CAT10 refers to the tenth polymorphic band (bands numbered from high to low molecular weight) amplified with the primer combination EcoRI-AGG and MseI-CAT. Estimating the size of the bands was difficult due to problems with the marker standard.

Cloning and sequencing of AFLP fragments. The two AFLP fragments closest to the resistance gene (EcoRI-AGG/MseICAT10 and EcoRI-ACTG/MseI-CAAA5) were isolated, re-amplified to confirm the correct size, and cloned with the TA cloning kit (Invitrogen, Carlsbad, CA). Ten independent clones from each band were sequenced with an ALF Express System automated sequencer (Amersham Pharmacia Biotech Inc., Piscataway, NJ).

Microsatellite analysis. A total of 240 microsatellite primer pairs specific for all wheat chromosomes was selected $(36,39)$ and evaluated for linkage with the $S t b 4$ gene. In addition, two random amplified polymorphic DNA primers (UBC219 and UBC261) linked to the leaf rust resistance gene $\operatorname{Lr} 29$ (37) also were evaluated for linkage to $S t b 4$. All primers were synthesized by MWG Biotech Inc. (Charlotte, NC). Polymerase chain reactions (PCRs) were performed as described previously $(1,2)$ with the Hot Star Taq DNA polymerase kit (Qiagen Inc., Valencia, CA). Each PCR $(25 \mu \mathrm{l})$ contained $5.8 \mu \mathrm{l}$ of sterile deionized water, $4 \mu \mathrm{l}$ of $10 \times \mathrm{Q}$ solution, $2 \mu \mathrm{l}$ of $10 \times$ PCR buffer, $1 \mu \mathrm{l}$ of $25 \mathrm{mM} \mathrm{MgCl}_{2}, 2 \mu \mathrm{l}$ of $10 \mathrm{mM}$ dNTPs, $4 \mu \mathrm{l}$ of primer solution ( $4 \mu \mathrm{M}$ each), $0.2 \mu \mathrm{l}$ of Hot

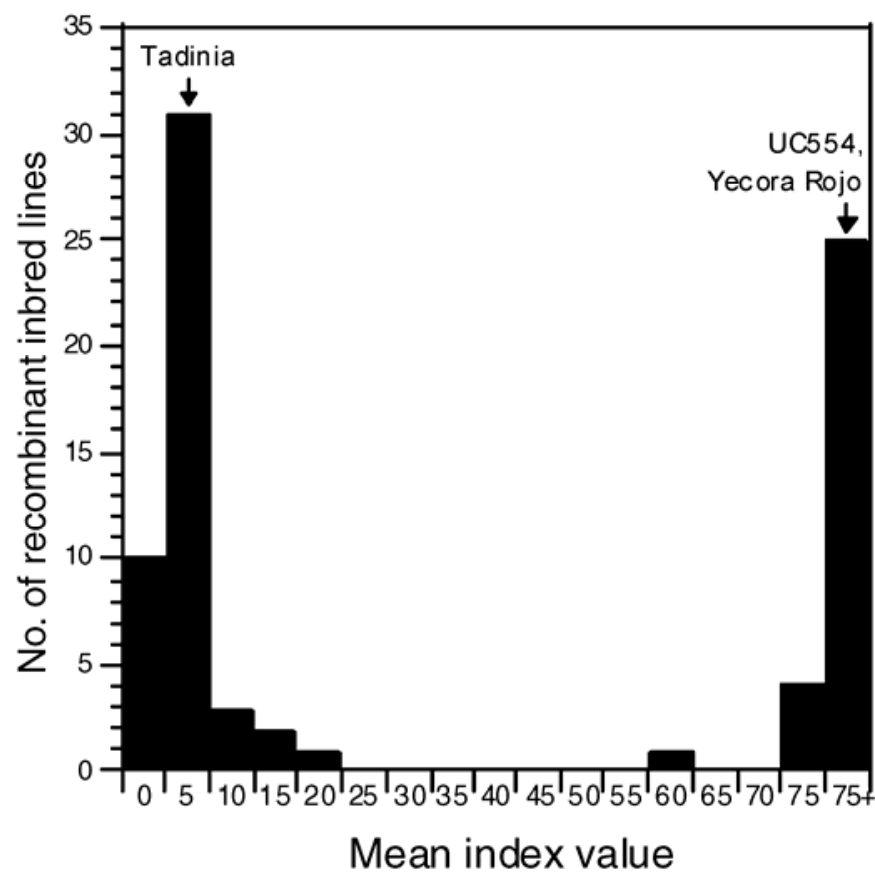

Fig. 1. Segregation of resistance to Mycosphaerella graminicola isolate IN95Lafayette-1196-WW-1-4 in progeny of the wheat cross Tadinia $\times$ (Yecora Rojo $\times$ UC554). Histogram showing the frequency distribution of a multiplicative index of Septoria tritici blotch severity and pycnidial density averaged over 2 years of greenhouse testing among $77 \mathrm{~F}_{10}$ recombinant-inbred lines. Each bar of the histogram is labeled with the maximum value for that class. The classes containing the mean index values of the three parents are indicated by vertical arrows.
Star Taq DNA polymerase (5 units/ $\mu \mathrm{l})$, and $6 \mu \mathrm{l}(6 \mathrm{ng} / \mu \mathrm{l})$ of template DNA. PCR reactions were performed in a PTC-100 thermal cycler (MJ Research, Watertown, MA) at standard amplifications of $94^{\circ} \mathrm{C}$ for $3 \mathrm{~min}$, followed by 44 cycles of $94^{\circ} \mathrm{C}$ for $1 \mathrm{~min}$; 50,55 , or $60^{\circ} \mathrm{C}$ (based on primer annealing temperature) for $1 \mathrm{~min}$; and $72^{\circ} \mathrm{C}$ for $2 \mathrm{~min}$, with a final extension at $72^{\circ} \mathrm{C}$ for 7 min before cooling to $4^{\circ} \mathrm{C}$. PCR products were separated by electrophoresis in 3\% agarose gels (Amresco, Solon, OH) at $4 \mathrm{~V} / \mathrm{cm}$ in $0.5 \times$ Tris-acetate EDTA (TAE) buffer (0.02 M Tris, $0.0095 \mathrm{M}$ glacial acetic acid, and 0.005 M EDTA).

To further confirm polymorphism, PCR products were separated on $12 \%$ (29:1 acrylamide/Bis) nondenaturing polyacrylamide gels (398 by 338 by $0.4 \mathrm{~mm}$ ) as described by the manufacturer (Promega Corp., Madison, WI). Band sizes were estimated relative to a 25-bp DNA size-standard ladder (Invitrogen, Carlsbad, CA). After electrophoresis at $60 \mathrm{~W}$ for $2 \mathrm{~h}$, PCR products were detected by silver staining as described previously $(1,2)$. The gel was dried and photographs were taken with a Polaroid camera (Fotodyne Inc., Hartland, WI).

Aneuploid analysis. To confirm the chromosomal location of the Stb4 gene, genomic DNA from wheat cv. Chinese Spring (CS), six nulli-tetrasomic (NT) lines of CS (N7AT7B, N7AT7D, N7BT7D, N7BT7A, N7DT7A, and N7DT7B), and the resistant and susceptible parents was analyzed with the five microsatellite primer pairs for loci Xgwm44, Xgwm111, Xgwm295, Xgwm428, and Xgwm437. The presence or absence of the corresponding characteristic PCR band was compared among the NT lines and three parents. Further amplification with microsatellite primer Xgwm111 and the two AFLP primer combinations AGG/CAT10 and ACTG/CAAA5 was performed using DNA from Thatcher (TC), one CS ditelosomic line CS DT7DS (missing the long arm of chromosome 7D), and the two Canthatch (CTH) ditelosomic lines DT7DS (missing the long arm of chromosome 7D) and CTH DT7DL (missing the short arm of 7D).

Linkage analysis. Segregating molecular markers were scored in each RIL as either (i) Tadinia-type for resistance or (ii) (Yecora Rojo $\times$ UC554)-type for susceptibility. Then, $\chi^{2}$ values were used to test the hypothesis of segregation of resistance versus susceptibility and presence and absence of AFLP or microsatellite markers for a 1:1 ratio. Goodness-of-fit values were calculated for all segregation ratios and $P<0.05$ was selected as the level for rejecting the null hypothesis. Linkage analysis was performed with the MAPMAKER program (version 2.0 for Macintosh) (25). The Kosambi (24) mapping function was used to convert recombination data into centimorgans (cM). The marker order was obtained by a multipoint analysis. The linkage map was plotted by selecting 0.4 as the maximum recombination fraction and 3.0 as the minimum logarithm of the odds ratio.

Analysis of disease scores and molecular markers. The relationship between measures of disease and the SSR marker Xgwm111 was visualized with paired scatter plots made with DeltaGraph (version 4.0.5). Consistency between the two greenhouse experiments and the field data was analyzed similarly. This approach tested how well the molecular markers predicted resistance or susceptibility in the greenhouse and field experiments.

\section{RESULTS}

Inheritance of STB resistance. In the Indiana greenhouse tests, the phenotypes of the RILs were either highly resistant like Tadinia or very susceptible like Yecora Rojo and UC554. The mean disease index separated the parents and all of the RILs into resistant (R) or susceptible (S) classes (Fig. 1); parents and RILs with a disease index of 20 or less were considered resistant, while those with a mean index of more than 55 were scored as susceptible. All but one of the susceptible RILs had mean disease index greater than 70, whereas all but six of the resistant RILs had an index of 5 or less (Fig. 1). The mean disease index values for the 
parents were 1.4 for Tadinia (R), 160.0 for Yecora Rojo (S), and 215.1 for UC554 (S). The observed segregation ratio of resistant $(n=47)$ to susceptible $(n=30)$ RILs in the Indiana greenhouse tests had more resistant lines than expected but was not different from $1: 1\left(\chi^{2}=3.75,0.05<P<0.10\right)$, supporting segregation of a single locus. Segregation of the RILs did not fit the 3:1 $\left(\chi^{2}=8.00\right.$, $P<0.005)$ ratio expected for two independent genes.

In the greenhouse tests with the Argentina isolate, RILs with disease scores from 0.3 to 1.5 were considered resistant, whereas those with scores from 1.8 to 4.6 were classified as susceptible due to a gap from 1.5 to 1.8 in the histogram of the results (data not shown). Resistance to STB segregated among the $77 \mathrm{~F}_{10}$ RILs in a $1: 1$ ratio $\left(\mathrm{R}: \mathrm{S}=35: 42, \chi^{2}=0.64,0.25<P<0.50\right)$, confirming the existence of a single gene.

The field trials with the Brazil isolate also gave a good discrimination between RILs that were resistant (DLA from 0 to 1.3) versus those that were susceptible (DLA from 2.0 to 5.1) (data not shown). The 30:47 ratio of R:S RILS showed a slight excess of susceptible plants, but was not significantly different from $1: 1\left(\chi^{2}=\right.$ $3.75,0.05<P<0.10)$. No heterogeneity in response to the disease was observed within the rows indicating homozygosity of the resistance gene.

AFLP analysis. In all, $\approx 90 \%$ of the 80 AFLP primer combinations tested produced clearly separated band patterns. On average, each primer combination produced $\approx 145$ scorable bands; therefore, the total number of loci assayed over the 72 combinations that gave good amplification was more than 10,000. Among these, 26 primer combinations gave one or more bands in BSA that potentially were linked to $S t b 4$. When tested with individual DNA of the 10 STB-resistant and 10 STB-susceptible lines used to make the resistant and susceptible bulks, more than half (14 of 26) of these potential linkages were confirmed and these selected primer combinations were used to determine the association between molecular markers and phenotypes in $70 \mathrm{~F}_{10}$ RILs (Fig. 2). Amplified DNA fragments ranged in size from 30 to $800 \mathrm{bp}$, but most polymorphic bands were fewer than 500 bp in size. Each polymorphic primer combination yielded from 112 to 177 amplified DNA bands, with 2 to 15 bands appearing polymorphic between the parents and the bulks. To simplify the banding patterns, some primers that gave potentially useful amplification profiles were extended by adding an additional selective nucleotide to their $3^{\prime}$ ends. AFLP primer combinations with four selective nucleotides amplified fewer bands than those with three selective nucleotides, which gave better separation on the gels. However, AFLP amplification with four selective nucleotides produced a slightly different profile of polymorphism compared with the same primers with only three selective nucleotides (data not shown).
Microsatellite analysis. Among the 240 microsatellite primers tested, only the primer pair Xgwmll1 amplified a specific DNA fragment related to STB resistance, based on polymorphism between the DNA of resistant and susceptible plants. An $\approx 210$-bp DNA fragment from the resistant parent Tadinia and resistant progeny appeared to be linked to the Stb4 gene (Fig. 3). Other microsatellite loci linked to $\mathrm{Xgwm} 111$ were either monomorphic or, for Xgwm44, gave segregation patterns with bands that could not be interpreted accurately.

Chromosomal location of Stb4. The 7D location of microsatellite locus Xgwmll1 and the positive controls Xgwm44, Xgwm295, Xgwm428, and Xgwm437 (39) was confirmed using CS NT lines. These microsatellites amplified the specific DNA fragment from CS and all of the NT lines except for N7DT7A and N7DT7B. Because there has been some confusion about the arm location of Xgwm111 (27,39), we retested this microsatellite with CS and CTH ditelosomic stocks. An $\approx 210$-bp-specific PCR band was amplified by the Xgwm111 primers in TC, CS, CS DT7DS, and CTH DT7DS, but was absent in CTH DT7DL (Fig. 4). These results confirmed the mapping of Xgwmll1 to the short arm of chromosome 7D. However, both AFLP markers (AGG/CAT10 and ACTG/CAA5) amplified a fragment from both CS DT7DS

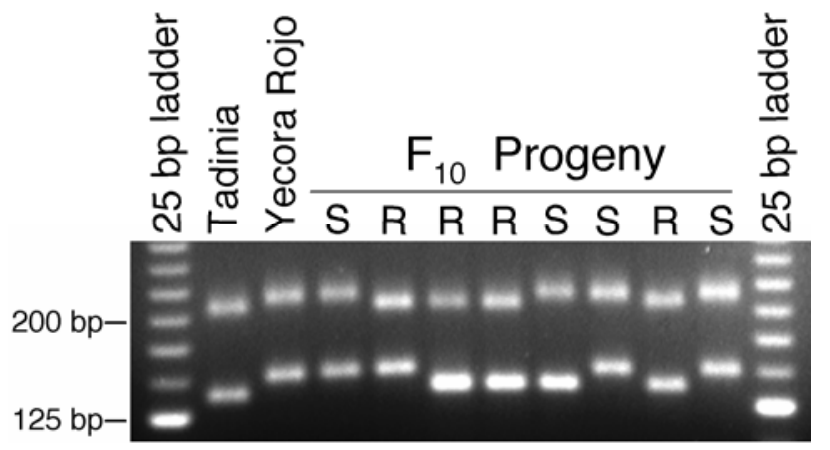

Fig. 3. DNA bands amplified from two parents and eight $\mathrm{F}_{10}$ recombinantinbred lines derived from a cross between the resistant wheat cv. Tadinia (Stb4 gene for resistance to isolate IN95-Lafayette-1196-WW-1-4 of Mycosphaerella graminicola) and the susceptible parent (Yecora Rojo $\times$ UC554) with the microsatellite primer pair for locus Xgwm111 shown in a $3 \%$ agarose gel. A 25-bp DNA ladder was used as a standard size marker. Resistant and susceptible progeny are indicated by $\mathrm{R}$ and $\mathrm{S}$, respectively. An $\approx 210$-bp DNA fragment is amplified from the resistant parent Tadinia and resistant progeny compared with a band of $\approx 220 \mathrm{bp}$ in the susceptible parent and progeny. Locations of 125- and 200-bp size-standard bands are indicated on the left. A second locus segregates among these progeny but is not linked to the resistance gene.

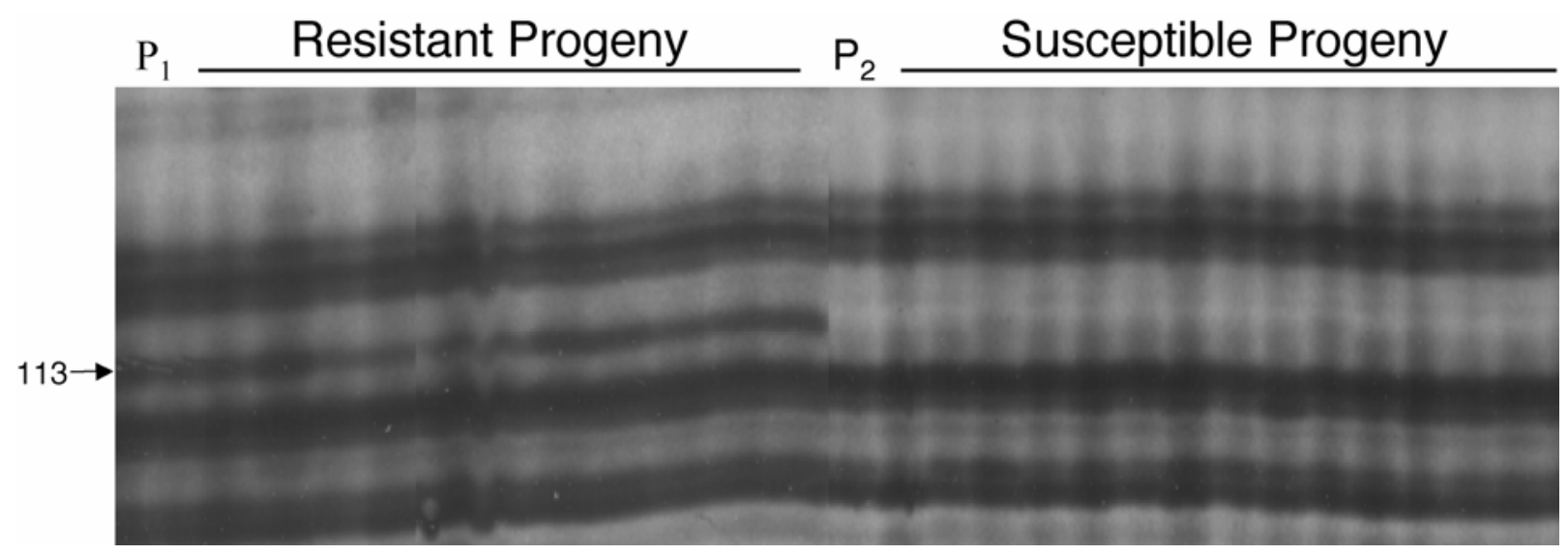

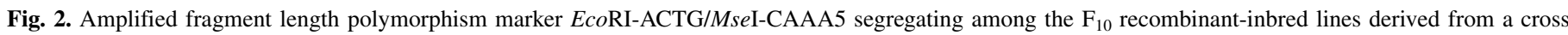

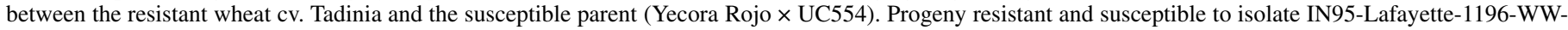

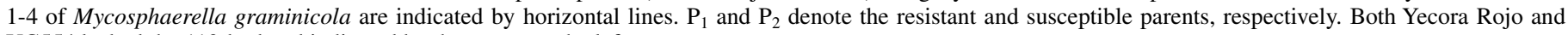
UC554 lacked the 113-bp band indicated by the arrow on the left. 
and CTH DT7DL; therefore, they could not be located to a specific chromosome arm.

Linkage analysis and genetic mapping. A total of 15 molecular markers was used for linkage analysis. Among these, 12 markers (11 AFLP and 1 microsatellite) formed a linkage group

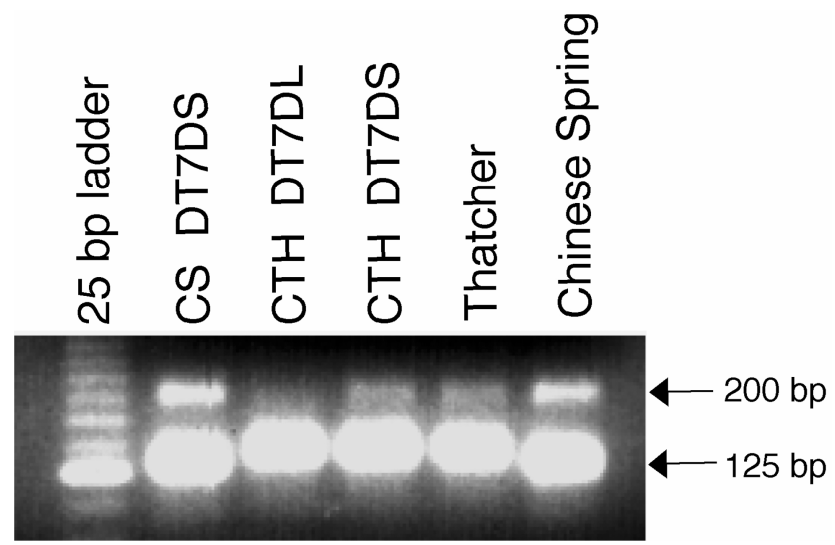

Fig. 4. Comparison of polymerase chain reaction (PCR) bands amplified with chromosome-specific microsatellite primer pair Xgwm111 using ditelosomic wheat stocks. PCR products were separated by electrophoresis in a $3 \%$ agarose gel. A specific band of $\approx 210 \mathrm{bp}$ (indicated by the arrow) present in ditelosomic stocks Chinese Spring (CS) DT7DS, Canthatch (CTH) DT7DS, Thatcher, and CS but absent in CTH DT7DL, confirms that Xgwm111 is located on the short arm of chromosome 7D.

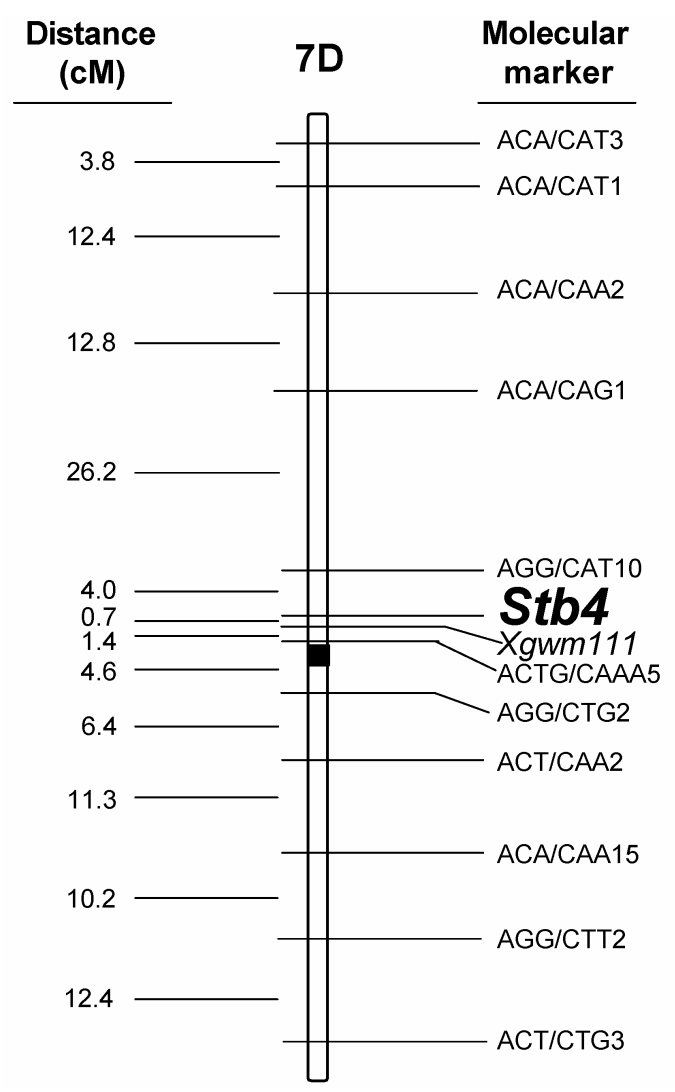

Fig. 5. Amplified fragment length polymorphism (AFLP) and microsatellite linkage map constructed from the $\mathrm{F}_{10}$ recombinant-inbred lines derived from the resistant cv. Tadinia crossed with the susceptible parent (Yecora Rojo $\times$ UC554). Distances in centimorgans (cM) are indicated on the left; molecular markers and the resistance locus are on the right. Gene Stb4 controls resistance to isolate IN95-Lafayette-1196-WW-1-4 of the Septoria tritici blotch pathogen Mycosphaerella graminicola. The black area denotes one possible position for the centromere. However, the orientation of Stb4 with regard to Xgwm111 is uncertain and could be the reverse of what is shown here. Map distances are proportional to the distances in $\mathrm{cM}$. with Stb4 (Fig. 5). The microsatellite and four of the five AFLP markers that were most closely linked to Stb4 gave segregations that were consistent with a 1:1 ratio (Table 1). All six of the most closely linked molecular markers were in coupling with the resistance allele. The 113-bp AFLP marker EcoRI-ACTG/MseICAAA5 and microsatellite marker $X g w m 111$ were on one side of the $S t b 4$ gene at distances of 2.1 and $0.7 \mathrm{cM}$, respectively, while AFLP AGG/CAT10 was $4 \mathrm{cM}$ from Stb4 on the flanking side (Fig. 5). Analysis of these markers mapped Stb4 near the centromere on the short arm of chromosome 7D.

Analysis of disease scores relative to molecular markers. The plot of pycnidial density versus disease severity revealed two main clusters of RILs near the values for the resistant and susceptible parents (Fig. 6A). All RILs with a severity $>10 \%$ also had the same allele as the susceptible parent at SSR locus Xgwm111, whereas those with a severity $<10 \%$ had the Tadinia allele, with only four exceptions (Fig. 6A). Three of these exceptions had been scored as possibly susceptible during the 2000 test but, due to poor germination, were not included during the 2001 test in which severity values generally were higher. These lines were retested during 2002 when severity levels also generally were low. The fourth exceptional line consistently was scored as resistant even though it had the susceptible-associated allele at locus Xgwm111 and the other molecular markers tested. Four of the RILs were recombinant for one or more of the molecular marker loci, but always had the phenotype predicted by marker Xgwm111 (data not shown). All RILs scored as susceptible had a pycnidial density greater than 1.7 (Fig. 6A).

The plot of mean pycnidial density in the Indiana greenhouse test versus mean severity in the Brazil greenhouse test with an isolate from Argentina showed a different response (Fig. 6B). Many RILs that were scored as resistant to the Indiana isolate and had the resistance-associated marker allele were susceptible to the Argentina isolate, and the converse also occurred; many RILs that were susceptible to the Indiana isolate and had the susceptibleassociated marker allele were very resistant to the Argentina isolate (Fig. 6B). When the plot was divided into quadrats based on a value of 1.7 to distinguish between resistant and susceptible responses for both the Indiana and Argentina isolates, the number of RILs in each quadrat was (clockwise, beginning in the upper left) 19:21:13:17, which fits a ratio of $1: 1: 1: 1\left(\chi^{2}=2.0,0.5<P<0.75\right)$.

A similar pattern was seen in the plot between the Indiana greenhouse pycnidial density data and the mean severity with a Brazil isolate in the field (Fig. 6C). When divided into quadrats as described above, the ratio of the RILs was 20:24:10:16, which is consistent with a $1: 1: 1: 1$ ratio $\left(\chi^{2}=6.11,0.10<P<0.25\right)$.

The pattern was different when the Argentina isolate greenhouse data were plotted against those for the Brazil isolate from

TABLE 1. Segregation of the six molecular markers closest to the Stb4 gene for resistance to isolate IN95-Lafayette-1196-WW-1-4 of Mycosphaerella graminicola among $70 \mathrm{~F}_{10}$ recombinant-inbred lines of wheat derived from the three-way cross Tadinia $\times($ Yecora Rojo $\times$ UC554)

\begin{tabular}{lccc}
\hline Marker $^{\mathrm{a}}$ & Tadinia & ${\text { Yecora Rojo } \times \mathrm{UC554}^{\mathrm{b}}}^{\mathrm{b}}$ & $\chi^{2 \mathrm{c}}$ \\
\hline E-AGG/M-CAT10 & 37 & 33 & 0.23 \\
E-ACTG/MCAAA5 & 37 & 33 & 0.23 \\
E-AGG/M-CTG2 & 37 & 33 & 0.23 \\
E-ACT/M-CAA2 & 41 & 29 & 2.06 \\
E-ACA/M-CAA15 & 44 & 26 & 4.66 \\
$X g w m 111$ & 36 & 34 & 0.06
\end{tabular}

a Names of amplified fragment length polymorphism markers consist of selective nucleotides from primers for $E c o$ RI and for MseI separated by a slash; the microsatellite marker is indicated by italics. All markers are linked in coupling with the resistance gene.

b The patterns for Yecora Rojo and UC554 were distinct from Tadinia and scored as a single marker.

${ }^{c}$ Goodness of fit $\left(\chi^{2}\right)$ of the ratios of the molecular markers among $70 \mathrm{~F}_{10}$ recombinant-inbred lines expected for a single gene $(1: 1) ; \chi^{2}$ values greater than 3.84 indicate a poor fit to a $1: 1$ segregation ratio $(P<0.05)$. 
the field (Fig. 6D). Although some RILs occurred in all four quadrats, the ratio was significantly different from $1: 1: 1: 1\left(\chi^{2}=\right.$ $26.69, P<0.005)$. Most RILs were in the upper right or lower left quadrats, as expected if both isolates identify the same gene. The ratio of RILs in these two quadrats was $34: 20$, consistent with a $1: 1$ ratio $\left(\chi^{2}=3.63,0.05<P<0.10\right)$. In all, $\approx 50 \%$ of the RILs in each quadrat had the susceptible-associated marker allele, as expected if the resistance gene identified with the Argentina and Brazil isolates is different from Stb4.

\section{DISCUSSION}

The multiplicative disease index combined data for both severity and pycnidial density into a single number and allowed easy

A
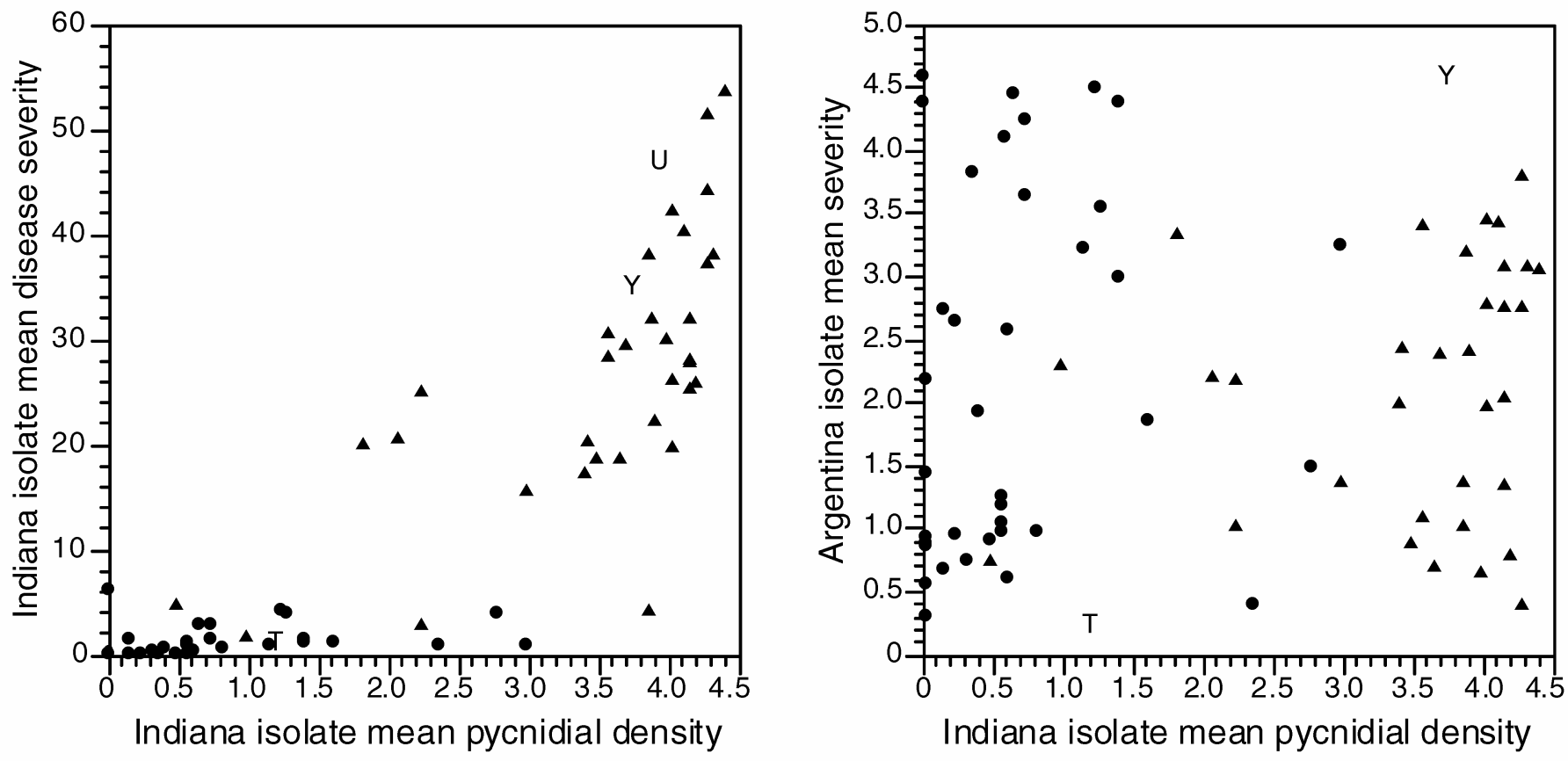

C
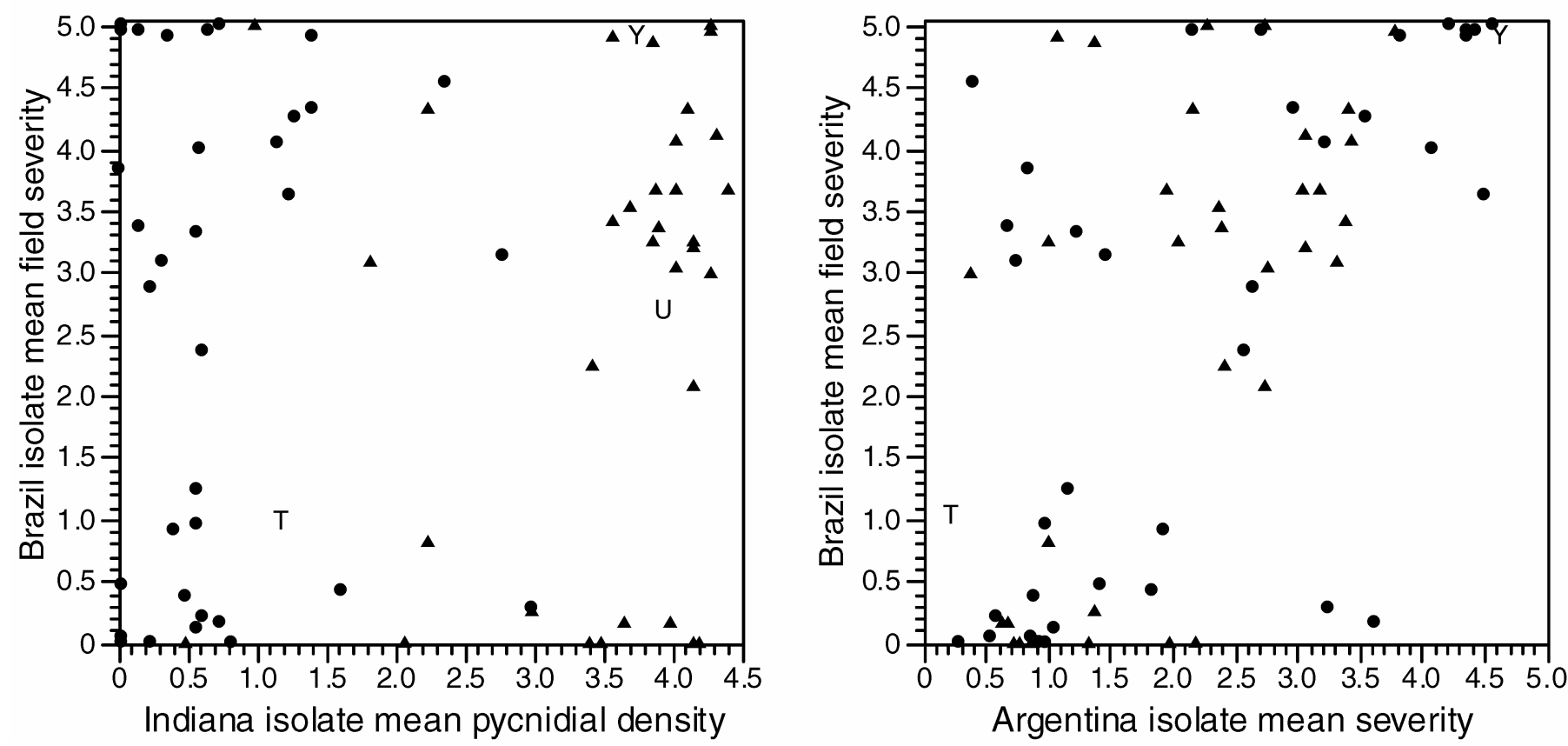

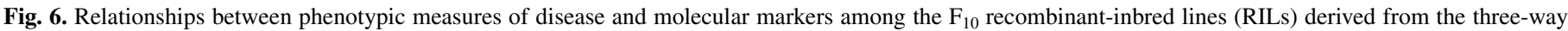

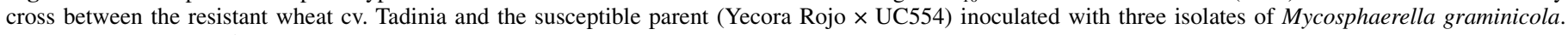

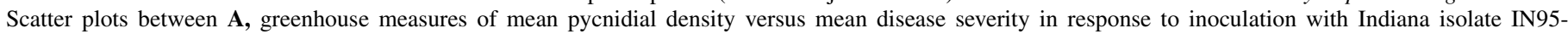

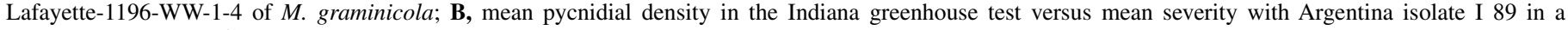

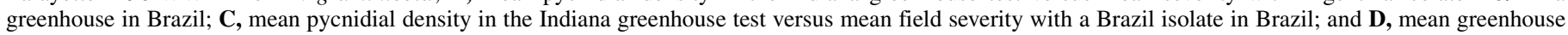

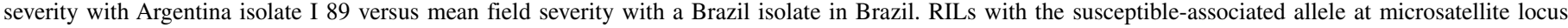

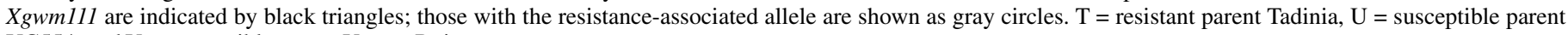
UC554, and Y = susceptible parent Yecora Rojo. 
separation of resistant and susceptible RILs. The accuracy of the index prediction was confirmed with the molecular markers. Previous studies had shown that pycnidial production alone is a better indicator of resistance or susceptibility than severity, because some lines can give large lesions with little or no sporulation (23). However, in our analysis, either measure could have provided effective separation of resistant and susceptible RILs. Only four lines had a different phenotype than predicted by the molecular markers, and three of these may have been because they were not tested during 2001 when severity values were highest. The fourth line could have been a rare double recombinant with the resistance allele inserted among the susceptible-associated marker alleles. A more likely explanation may be that this sample was mislabeled during the testing process. Unfortunately, the four exceptional RILs had all of the susceptible-associated marker alleles and, therefore, could not have been single recombinants. The low number of exceptional RILs makes the interaction of additional genetic factors an unlikely explanation.

The resistance locus in Tadinia, identified with an Indiana isolate of $M$. graminicola, mapped very near the centromere on the short arm of chromosome 7D. This resistance is assumed to be the same as the Stb4 gene in Tadinia named previously (47). However, the greenhouse test with an isolate of $M$. graminicola from Argentina and the field experiment with an isolate from Brazil identified a second likely major gene for resistance to STB in this cultivar. With the present data, it is impossible to be certain which gene is the same as Stb4 and which may represent a new gene. Therefore, we arbitrarily designate the gene identified with the Indiana tester isolate as $\mathrm{Stb} 4$ and assume the additional gene is either new or the same as one of those named previously. Additional testing with the same California isolate used originally to name $S t b 4$ will be required to answer this question definitively.

Mapping of the Stb4 locus was expedited by the use of BSA with AFLPs and microsatellites. The AFLP primer pairs with three selective nucleotides at the $3^{\prime}$ end generated complicated banding patterns that were difficult to score accurately compared with those with four selective nucleotides. Furthermore, the polymorphisms obtained from the AFLP primers with three and four nucleotides at the $3^{\prime}$ end were different and were difficult to compare due to the large numbers of bands involved (data not shown). Similar results were reported previously by Bai et al. (5), who recommended combinations of primers with three and four, or four and four, selective nucleotides for wheat AFLP analysis. Using four and four AFLP selective nucleotides allowed us to identify a 113-bp AFLP marker, EcoRI-ACTG/MseI-CAAA5, that was closely linked to the Stb4 locus in wheat.

In this study, the mapping population used was a three-way cross generated by the breeding program at the University of California. The susceptible parent was an $F_{1}$ from the cross Yecora Rojo $\times$ UC554. Thus, we might expect only $25 \%$ of the polymorphic bands in the RIL population to have been derived from Yecora Rojo and another 25\% to have originated from UC554. The resistant parent Tadinia should be the origin for the remaining $50 \%$ of the polymorphic bands. With some exceptions in microsatellite analysis, both susceptible cvs. Yecora Rojo and UC554 contained similar-sized bands, and all three parents often were monomorphic. This low level of DNA polymorphism can be attributed to the high degree of relatedness among the three parental wheat cultivars, which are all elite germ plasm in the breeding program for improved red spring wheat cultivars at the University of California, Davis.

Our attempts to convert AFLP bands into easily assayed PCRbased markers were not successful, presumably because the polymorphism was near the $3^{\prime}$ end of the original primer sequence or was within one of the restriction-enzyme recognition sites. To test this hypothesis, inverse PCR (8) was used to extend the sequences in both directions. Unfortunately, primers designed within the flanking regions also gave a product of similar size, which could not discriminate between resistant and susceptible individuals.

Problems in converting these AFLP markers are compounded by the use of EcoRI as the six-base cutter in the AFLP analysis. This enzyme is insensitive to cytosine methylation and often gives AFLP fragments corresponding to repetitive sequences that cannot be used as RFLP markers $(6,7)$. In contrast, methylationsensitive enzymes such as PstI give a higher frequency of polymorphisms in hypomethylated regions of the genome which are more likely to be single copy rather than repetitive (50). AFLP analysis with $P s t \mathrm{I}$ rather than EcoRI as the six-base cutter may give bands with a higher probability of being converted into a simpler type of marker system.

Among the seven STB resistance loci mapped previously, all but one are on different chromosomes from Stb4. Gene Stbl mapped to the long arm of chromosome 5B (3), Stb2 is on the distal region of the short arm of chromosome 3B, and the Stb3 gene is on the short arm of chromosome 6D (2). The Stb6 gene was mapped to the distal part of the short arm of chromosome $3 \mathrm{~A}$ (9) and gene $S t b 7$ is located on the long arm of chromosome $4 \mathrm{~A}$ (30). The most recently identified gene, $S t b 8$, was mapped to the long arm of chromosome 7B (1). All of these must be distinct from $S t b 4$ on chromosome 7D.

The seventh mapped gene, Stb5, was located to the short arm of chromosome 7D with microsatellite, RFLP, and morphological markers (4). The closest loci were microsatellite Xgwm44 and the morphological marker for red coleoptile, $R c 3$, which flanked the Stb5 gene at distances of 7.2 and $6.6 \mathrm{cM}$, respectively. Microsatellite $\mathrm{Xgwm} 111$ also was linked to Stb5, but at a distance of $11.9 \mathrm{cM}(4)$, and was indicated as mapping to the other side of the centromere (on the long arm) of chromosome 7D opposite Stb5. More recent analyses have shown that Xgwm111 maps to the short arm rather than the long arm of chromosome 7D (27). This conclusion was supported by our analysis of ditelosomic stocks, indicating that Stb4 and Stb5 both are probably on the short arm of chromosome 7D.

It is intriguing that both Stb4 and Stb5 are located near the centromere of wheat chromosome 7D. These genes could be identical, allelic, or different but linked. The only marker in common between the two maps is microsatellite Xgwm 111, which is $0.7 \mathrm{cM}$ from Stb4 but $11.9 \mathrm{cM}$ from Stb5. The difference between these distances is significant $(P<0.05)$; however, because they were calculated from different mapping populations, it is not clear if these loci really are distinct. Unfortunately, none of the AFLP markers was mapped in the Stb5 population, and loci Xgwm44 and $R c 3$ were not informative in our Stb4 mapping population; therefore, it is not possible to determine the map order between the other linked markers and the resistance loci Stb4 and Stb5. A California isolate of $M$. graminicola was unable to differentiate wheat lines containing Stb4 and Stb5 in limited inoculation tests (S. B. Goodwin, unpublished data), but it is not known whether that means the resistance genes are the same or if the California isolate simply is avirulent to both. Therefore, with the present data, it is not possible to determine with certainty if Stb4 and Stb5 are allelic variants of the same gene or different but closely linked genes. These competing hypotheses must be tested by additional genetic analyses and by reciprocal pathogenicity tests with the isolates used here and by Arraiano et al. (4).

In addition to Stb4 and Stb5, this region of chromosome 7DS also contains several genes for resistance to the Russian wheat aphid, Diuraphis noxia (26,27). Genes Dn1, Dn2, Dn5, Dn6, and $D n x$ are located from 1.5 to $3.8 \mathrm{cM}$ from microsatellite locus Xgwm111. These distances are intermediate between those estimated for Stb4 and Stb5 from the same microsatellite, which might indicate that the genes for resistance to STB flank those for resistance to Russian wheat aphid. Therefore, this region of chromosome 7DS may contain a large cluster of resistances and could 
be a good location to search for additional genes with specificities for diverse pests and pathogens.

Other interesting genes located on chromosome 7DS include several for resistance to leaf rust, such as $\operatorname{Lr} 29(37,40), \operatorname{Lr} 34$ (32,35), and $L r 43$ (21), the stripe rust resistance gene $\operatorname{Yr} 18$ (45), and the Barley yellow dwarf virus resistance gene $B d v 1$ (46), which all are closely linked to Lr34. However, Lr34 mapped approximately $30 \mathrm{cM}$ distal to $R c 3$ and was unlinked to the centromere (12); therefore, these additional genes are not part of the same cluster as $S t b 4$ and the $D n$ genes. At least two resistance gene clusters occur on the short arm of chromosome 7D, one (containing Stb4) near the centromere and the second (with the rust resistance genes) located much more distally.

The resistance conferred by the $S t b 4$ gene was effective in the field in California from 1975 through the late 1990s (47). However, the effectiveness of this gene decreased dramatically recently. Some resistant cultivars developed from Tadinia (e.g., RSI5 and Kern) were susceptible, with up to $25 \%$ leaf area infected in parts of the Sacramento Valley of California during 2000 (22). This indicates that the pathogen is capable of overcoming this single-gene resistance. Sexual reproduction of $M$. graminicola is known in California (29) along with high levels of genetic diversity for molecular markers within populations $(11,31)$. It is likely that variability also occurs for pathogenicity, which should allow for rapid shifts in virulence of the populations (23). On the other hand, pathogenic specialization of this fungus is less distinct (13) than that of some other wheat pathogens, even though genefor-gene interactions are known to occur in this pathosystem (9). The use of this gene in wheat improvement may still be valuable in California and other parts of the United States when in combination with other STB resistance genes.

Breeding for resistance to STB cannot be performed in areas where weather conditions are adverse for disease development. In addition, environmental influences on symptom expression may result in inaccurate disease assessments. Introgression of genes for resistance against $M$. graminicola into new wheat cultivars is further compounded by the long latent period of the disease (typically at least 18 days in the greenhouse, usually longer), and the lack of defined tester isolates to identify specific resistance genes in gene pyramids. Microsatellite Xgwm111 is a PCR-based, genome-specific, co-dominant marker that displays a specific allele linked to $S t b 4$ at a distance of only $0.7 \mathrm{cM}$. This marker will facilitate pyramiding Stb4 with other STB resistance genes into a single wheat cultivar for more durable resistance to M. graminicola.

\section{ACKNOWLEDGMENTS}

Published as paper 17421, Purdue University Agricultural Research Programs. This work was supported by USDA CRIS project 3602-22000013-00D and USDA-IFAFS competitive grant 2001-04462. The research in Brazil was supported by FAPESP (Fundação de Amparo a Pesquisa do Estado de São Paulo). We thank F. Urmeev, B. Roberts, J. Breeden, B. Wallace, and K. Brikmanis for performing the greenhouse experiments; and B. Gill for providing seeds of the Canthatch ditelosomic stocks.

\section{LITERATURE CITED}

1. Adhikari, T. B., Anderson, J. M., and Goodwin, S. B. 2003. Identification and molecular mapping of a gene in wheat conferring resistance to Mycosphaerella graminicola. Phytopathology 93:1158-1164.

2. Adhikari, T. B., Wallwork, H., and Goodwin, S. B. 2004. Microsatellite markers linked to the Stb2 and Stb3 genes for resistance to Septoria tritici blotch in wheat. Crop Sci. 44:1403-1411.

3. Adhikari, T. B., Yang, X., Cavaletto, J. R., Hu, X., Buechley, G., Ohm, H. W., Shaner, G., and Goodwin, S. B. 2004. Molecular mapping of Stb1, a potentially durable gene for resistance to Septoria tritici blotch in wheat. Theor. Appl. Genet. 109:944-953.

4. Arraiano, L. S., Worland, A. J., Ellerbrook, C., and Brown, J. K. M. 2001. Chromosomal location of a gene for resistance to Septoria tritici blotch
(Mycosphaerella graminicola) in the hexaploid wheat 'Synthetic 6x'. Theor. Appl. Genet. 103:758-764.

5. Bai, G. H., Kolb, F. L., Shaner, G., and Domier, L. L. 1999. Amplified fragment length polymorphism markers linked to a major quantitative trait locus controlling scab resistance in wheat. Phytopathology 89: 343-348.

6. Bert, P. F., Charmet, G., Sourdille, P., Hayward, M. D., and Balfourier, F. 1999. A high-density molecular map for ryegrass (Lolium perenne) using AFLP markers. Theor. Appl. Genet. 99:445-452.

7. Boivin, K., Deu, M., Rami, J.-F., Trouche, G., and Hamon, P. 1999. Towards a saturated sorghum map using RFLP and AFLP markers. Theor. Appl. Genet. 98:320-328.

8. Braden, J. M., and Simon, P. W. 1998. Conversion of an AFLP fragment linked to the carrot $\mathrm{Y}_{2}$ locus to a simple, codominant PCR-based marker form. Theor. Appl. Genet. 97:960-967.

9. Brading, P. A., Verstappen, E. C. P., Kema, G. H. J., and Brown, J. K. M. 2002. A gene-for-gene relationship between wheat and Mycosphaerella graminicola, the Septoria tritici blotch pathogen. Phytopathology 92: 439-445.

10. Camacho-Casas, M. A., Kronstad, W. E., and Scharen, A. L. 1995. Septoria tritici resistance and associations with agronomic traits in a wheat cross. Crop Sci. 35:971-976.

11. Chen, R. S., and McDonald, B. A. 1996. Sexual reproduction plays a major role in the genetic structure of populations of the fungus Mycosphaerella graminicola. Genetics 142:1119-1127.

12. Dyck, P. L., Kerber, E. R., and Aung, T. 1994. An interchromosomal reciprocal translocation in wheat involving leaf rust resistance gene $\operatorname{Lr34}$. Genome 37:556-559.

13. Eyal, Z., Amiri, Z., and Wahl, I. 1973. Physiologic specialization of Septoria tritici. Phytopathology 63:1087-1091.

14. Eyal, Z., and Brown, M. B. 1976. A quantitative method for estimating density of Septoria tritici pycnidia on wheat leaves. Phytopathology 66:11-14.

15. Eyal, Z., Prescott, J. M., and van Ginkel, M. 1987. The Septoria Diseases of Wheat: Concepts and Methods of Disease Management. International Maize and Wheat Improvement Centre (CIMMYT), Mexico, D.F.

16. Eyal, Z., Scharen, A. L., Huffman, M. D., and Prescott, J. M. 1985. Global insights into virulence frequencies of Mycosphaerella graminicola. Phytopathology 75:1456-1462.

17. Gaunt, R. E., Thompson, W. J., and Sutcliffe, J. 1986. The assessment of speckled leaf blotch in winter wheat in New Zealand. Ann. Bot. (Lond.) 58:33-38.

18. Gieco, J. O., Dubcovsky, J., and Camargo, L. E. A. 2004. Interaction between resistance to Septoria tritici and phenological stages in wheat. Sci. Agric. (Piracicaba, Brazil) 61:422-426.

19. Gilbert, J., Woods, S. M., and Tekauz, A. 1998. Relationship between environmental variables and the prevalence and isolation frequency of leaf-spotting pathogens in spring wheat. Can. J. Plant Pathol. 20:158-164.

20. Gilchrist, D. G., Qualset, C. O., Martensen, A. N., Vogt, H. E., and Jackson, L. F. 1990. Registration of Tadinia wheat. Crop Sci. 30:1366.

21. Hussien, T., Bowden, R. L., Gill, B. S., and Cox, T. S. 1997. Chromosome location of leaf rust resistance gene Lr43 from Aegilops tauschii in common wheat. Crop Sci. 37:1764-1766.

22. Jackson, L. F., Dubcovsky, J., Gallagher, L. W., Wennig, R. L., Heaton, J., Vogt, H., Gibbs, L. K., Kirby, D., Canevari, M., Carlson, H., Kearney, T., Marsh, B., Munier, D., Mutters, C., Orloff, S., Schmierer, J., Vargas, R., Williams, J., and Wright, S. 2000. 2000 Regional barley and common and durum wheat performance tests in California. Agron. Prog. Rep. 272:1-56.

23. Kema, G. H. J., Annone, J. G., Sayoud, R., van Silfhout, C., van Ginkel, M., and de Bree, J. 1996. Genetic variation for virulence and resistance in the wheat-Mycosphaerella graminicola pathosystem. I. Interactions between pathogen isolates and host cultivars. Phytopathology 86:200-212.

24. Kosambi, D. D. 1944. The estimation of map distances from recombination values. Ann. Eugen. 12:172-175.

25. Lander, E. S., Green, P., Abrahamson, J., Barlow, A., Daly, M. J., Lincoln, S. E., and Newburg, L. 1987. MAPMAKER: An interactive computer package for constructing primary genetic linkage maps of experimental and natural populations. Genomics 1:178-181.

26. Liu, X. M., Smith, C. M., and Gill, B. S. 2002. Identification of microsatellite markers linked to Russian wheat aphid resistance genes Dn4 and Dn6. Theor. Appl. Genet. 104:1042-1048.

27. Liu, X. M., Smith, C. M., Gill, B. S., and Tolmay, V. 2001. Microsatellite markers linked to six Russian wheat aphid resistance genes in wheat. Theor. Appl. Genet. 102:504-510.

28. Mackie, W. W. 1929. Resistance to Septoria tritici in wheat. (Abstr.) Phytopathology 19:1139-1140.

29. Madariaga, R. B., Gilchrist, D. G., and Martensen, A. N. 1989. Presence and role of Mycosphaerella graminicola in California wheat. (Abstr.) Phytopathology 79:1141. 
30. McCartney, C. A. 2002. Inheritance and chromosomal location of racespecific resistance to Mycosphaerella graminicola in wheat. Ph.D. thesis. University of Manitoba, Winnipeg, Canada.

31. McDonald, B. A., and Martinez, J. P. 1990. DNA restriction fragment length polymorphisms among Mycosphaerella graminicola (anamorph Septoria tritici) isolates collected from a single wheat field. Phytopathology 80:1368-1373.

32. McIntosh, R. A., Wellings, C. R., and Park, R. F. 1995. Wheat Rusts. An Atlas of Resistance Genes. CSIRO Publications, East Melbourne, Australia.

33. Michelmore, R. W., Para, I., and Kesseli, R. V. 1991. Identification of markers linked to disease resistance genes by bulked segregant analysis: A rapid method to detect markers in specific genomic regions by using segregating populations. Proc. Natl. Acad. Sci. USA 88:9828-9832.

34. Murray, M. G., and Thompson, W. F. 1980. Rapid isolation of high molecular weight plant DNA. Nucleic Acids Res. 8:4321-4325.

35. Nelson, J. C., Singh, R. P., Autrique, J. E., and Sorrells, M. E. 1997. Mapping genes conferring and suppressing leaf rust resistance in wheat. Crop Sci. 37:1928-1935.

36. Pestsova, E., Ganal, M. W., and Röder, M. S. 2000. Isolation and mapping of microsatellite markers specific for the D genome of bread wheat. Genome 43:689-697.

37. Procunier, J. D., Townley-Smith, T. F., Fox, S., Prashar, S., Gray, M., Kim, W. K., Czarnecki, E., and Dyck, P. L. 1995. PCR-based RAPD/ DGGE markers linked to leaf rust resistance genes Lr29 and Lr25 in wheat (Triticum aestivum L.). J. Genet. Breed. 49:87-91.

38. Rillo, A. O., and Caldwell, R. M. 1966. Inheritance of resistance to Septoria tritici in Triticum aestivum subsp. vulgare 'Bulgaria 88'. (Abstr.) Phytopathology 56:897.

39. Röder, M. S., Korzun, V., Wendehake, K., Plaschke, J., Tixier, M.-H., Leroy, P., and Ganal, M. W. 1998. A microsatellite map of wheat. Genetics 149:2007-2023.
40. Roelfs, A. P., Singh, R. P., and Saari, E. E. 1992. Rust Diseases of Wheat: Concepts and Methods of Disease Management. International Maize and Wheat Improvement Centre (CIMMYT), Mexico, D.F.

41. Rosielle, A. A. 1972. Sources of resistance in wheat to speckled leaf blotch caused by Septoria tritici. Euphytica 21:152-161.

42. Shaner, G., and Finney, R. E. 1976. Weather and epidemics of Septoria leaf blotch of wheat. Phytopathology 66:781-785.

43. Shaner, G., and Finney, R. E. 1982. Resistance in soft red winter wheat to Mycosphaerella graminicola. Phytopathology 72:154-158.

44. Shipton, W. A., Boyd, W. R. L., Rosielle, A. A., and Shearer, B. L. 1971. The common Septoria diseases of wheat. Bot. Rev. 37:231-262.

45. Singh, R. P. 1992. Genetic association of leaf rust resistance gene Lr34 with adult plant resistance to stripe rust in bread wheat. Phytopathology 82:835-838.

46. Singh, R. P. 1993. Genetic association of gene $B d v 1$ for tolerance to barley yellow dwarf virus with genes Lr34 and Yr18 for adult plant resistance to rusts in bread wheat. Plant Dis. 77:1103-1106.

47. Somasco, O. A., Qualset, C. O., and Gilchrist, D. G. 1996. Single-gene resistance to Septoria tritici blotch in the spring wheat cultivar 'Tadinia'. Plant Breed. 115:261-267.

48. Vos, P., Hogers, R., Bleeker, M., Reijans, M., van der Lee, T., Hornes, M., Frijters, A., Pot, J., Peleman, J., Kuiper, M., and Zabeau, M. 1995. AFLP: A new technique for DNA fingerprinting. Nucleic Acids Res. 23:44074414.

49. Wilson, R. E. 1985. Inheritance of resistance to Septoria tritici in wheat. Pages 33-35 in: Septoria of Cereals: Proc. Workshop. A. L. Scharen, ed. Montana State University, Bozeman.

50. Young, W. P., Schupp, J. M., and Keim, P. 1999. DNA methylation and AFLP marker distribution in the soybean genome. Theor. Appl. Genet. 99:785-792.

51. Zhang, X., Haley, S. D., and Jin, Y. 2001. Inheritance of Septoria tritici blotch resistance in winter wheat. Crop Sci. 41:323-326. 